\title{
TAXING THE ABC TRANSACTION: A SUGGESTED APPROACH *
}

\section{The Nature and Present Taxation of the ABC Transaction}

The intricacies of the Internal Revenue Code have encouraged the development of a number of unusual business transactions designed to minimize the participants' taxes. One of the most significant of these has been the so-called $A B C$ transaction, ${ }^{1}$ which is used to finance the development of productive oil and gas properties. The $A B C$ is designed to secure maximum tax benefits for three individuals: $A$, the holder of the working interest ${ }^{2}$ in developed or substantially developed oil and gas properties; $\mathrm{B}$, an operator looking for new production areas; and $\mathrm{C}$, a financier who either has substantial funds of his own or can obtain a loan from a bank. ${ }^{3}$ The nature of the transaction may be illustrated by a simple example. If $A$ wishes to sell ${ }^{4}$ his working interest to $B$ for one million dollars, but $B$ has only 200,000 dollars on hand, B has two alternatives open to him. $\mathrm{He}$ may either make an outright purchase or employ the $A B C$ method. A comparison of the consequences of these two alternatives will show the tax minimization effects of the $A B C$.

If $\mathrm{B}$ chooses to make an ordinary purchase, he will have to borrow the other 800,000 dollars which he needs. The lender will then take a mortgage on the working interest of the property. Since $A$ will have disposed of his entire property on the sale to $B$, he will receive capital gains on the full one million dollar purchase price. As the oil pays out, $B$ will include all of the production proceeds in his income subject to either cost or percentage depletion. The loan will then be liquidated from

* The author wishes to express his gratitude to Parker C. Fielder, William H. Francis, Jr. Professor of Taxation, University of Texas and Visiting Professor of Law, University of Pennsylvania, 1964-65, whose criticisms and suggestions were of invaluable aid in the writing of this Comment.

1 For various examples of the ABC see, e.g., Montgomery, Federal Taxes 12.46 (39th ed. 1964); Lyon \& Eustice, Assigmment of Income: Frnit and Tree as Irrigated by the P. G. Lake Case, 14 So. CaL. Tax INst. 47, 67 (1962); McClure, Effect of Supreme Court Decision in Commissioner v. P. G. Lake et al. in Transfers of Production Payments, 7 OIL \& GAS TAX Q. 245, 255-56 (1958); Minyard, How To Determine the Tax Saving That Makes an ABC Deal Worthwhile, $12 \mathrm{~J}$. TAxATION 290 (1960); Wilkinson, $A B C$-From $A$ to $Z, 38$ Texas L. REv. 673 (1960); The "Nassant" Plan of Acquisition of Oil Properlies, 4 On \& GAS TAX Q. 214, 224-25 (1955). Some writers use the designation $C$ to refer to the individual termed $B$ in this Comment.

2 "A working interest is the label given the interest owned by the operator of the oil properties." Note, Federal Taxation of Oil Payment Transactions, 104 U. PA. L. REv. 1088 n.7 (1956).

3 See Comment, A Simplified Explanation of the $A B C$ Transaction, 10 Loyola L. Rev. 249-50 (1961).

4 The sale is often prompted by the seller's need to fulfill his lease obligations. One obligation which can cause obvious difficulties is the "continuous drilling clause" which requires repeated drilling within short periods. Id. at 249. 
the profits that remain after taxes. This is the usual tax consequence of any purchase-mortgage situation.

If the $A B C$ alternative is employed, completely different tax results may be obtained by $B$. These results are made possible by certain concepts currently employed in oil and gas taxation. Using the $A B C, B$ will purchase the working interest and equipment from $A$ for 200,000 dollars, and $\mathrm{A}$ will reserve a production payment in the amount of 800,000 dollars, plus a sum equal to six percent annually on the unliquidated balance of the payment and plus the aggregate total of taxes and expenses which will be charged to him because of his ownership of the oil payment. ${ }^{\overline{0}}$ This production payment is a right to receive the proceeds from a fraction of the oil produced by the oil property, free of development and operating costs, until a fixed sum of money has been obtained. ${ }^{6}$ Unlike a royalty, it is limited to a period less than the full life of the property. The reserved production payment has been classified as property retained by $\mathrm{A}$ rather than as part of the consideration received by $A$ from $B .{ }^{7}$ After the transfer to $\mathrm{B}, \mathrm{A}$ therefore allocates his basis in the property between the conveyed working interest and the retained production payment. ${ }^{8}$ Although $A$ has retained a production payment, present law treats $A$ as having made a "sale" of the underlying leasehold for capital gains purposes. The 200,000 dollars is therefore accorded the favorable capital gains rates.

Simultaneously with (or shortly after) the A-B transaction, A will sell the reserved production payment to $C .{ }^{9}$ To enable himself to purchase the production payment, $\mathrm{C}$ will usually make arrangements to borrow the needed 800,000 dollars from a bank. He will execute a promissory note which will obligate him to pay five percent interest annually and will pledge the production runs as collateral for the loan. ${ }^{10}$ Current law also treats the A-C conveyance as a capital transaction; A will therefore obtain the same rates for the full one million dollars that he receives in a purchasemortgage transaction. B's tax status, however, is considerably altered. The production payment in the $A B C$ is now considered to be a separate economic interest. Consequently, the proceeds attributable to it are in$A B C]$.

5 The Case for $A B C$, OII \& GAS TAX Q. 1, 2 (1961) [hereinafter cited as

64 Mertens, Federal Income Taxation \$ 24.23(b) (1960); Rowen, Introduction to Oil and Gas Interests, 34 TAXEs 19, 21 (1956); Trevathan, Federal Tax Aspects of Oil Production Payments, 35 Taxes 179 (1957).

7 E.g., United States v. Witte, 306 F.2d 81 (5th Cir. 1962), cert. denied, 371 U.S. $949^{\circ}$ (1963) (production payments on sand and gravel); Kline v. Commissioner, 268 F.2d 854 (9th Cir. 1959) ; Howard Glenn, 39 T.C. 427 (1962) (dictum).

8 See F. A. Gillespie \& Sons Co. v. Commissioner, 154 F.2d 913 (10th Cir.), cert. denied, 329 U.S. 781 (1946); Columbia Oil \& Gas Co. v. Commissioner, 118 F.2d 459 (5th Cir. 1941).

- Since the production payment is considered to be reserved property, its holding period for capital gains purposes dates back to the time the lease was acquired, rather than to the date the payment was reserved. Appleman, The ABC Transaction From the Standpoint of the Seller, 21 N.Y.U. INST. ON FED. TAX. 973, 975 (1963) [hereinafter cited as Seller].

$10 A B C 3$. 
cluded in the income of the owner of the payment rather than in the income of the owner of the underlying leasehold. ${ }^{11}$ The leasehold's production is therefore divided between $\mathrm{B}$ and $\mathrm{C}$ in proportion to their respective interests. Since the production payment proceeds will go to $\mathrm{C}, \mathrm{B}$ will be able to exclude the money needed to pay the "mortgage" (here C's investment) from his income and to obtain the benefit of both cost and percentage depletion. ${ }^{12}$ In turn, C's interest will entitle him to depletion. ${ }^{13}$ C's profit will be the difference between the interest added to the production payment and the interest paid to the bank on the loan. ${ }^{14}$ During the payout of the production payment, $\mathrm{B}$ will bear all the expenses of the operation ${ }^{15}$ - his share of the leasehold's production permits him to meet these costs. ${ }^{16}$

\section{Challenges to the Present Tax Treatment of the ABC Transaction}

\section{A. The Fate of the Carve Out}

Since the Internal Revenue Service has given favorable rulings to a number of $A B C$ 's over a period of years, the transaction has gained considerable popularity and has been the instrument through which millions of dollars have been invested in the oil and gas industry. ${ }^{17}$ Recent developments have cast doubt upon the tax status of the $\mathrm{ABC}$, however, and its future is presently unclear. One of these developments was the fate of the so-called "carve out." The sale of a production payment coupled with the retention of an underlying longer lived interest in the

11 Thomas v. Perkins, 301 U.S. 655 (1937).

12 Surrey \& Warren, Federal Income Taxatron 797 (1962). For figures which indicate the quantitative tax advantages of the $A B C$ to $B$, see Minyard, supra note 1 at 291-92; Rowen, The $A B C$ Transaction From the Viewpoint of the Purchaser of the Working Interest, 21 N.Y.U. INST. ON FED. TAX 957, 959 (1963) [hereinafter cited as Purchaser]; note 66 infra.

13 Early, The ABC Transaction From the Standpoint of the Oil Payment Purchaser and the Lender, 21 N.Y.U. INST. ON FED. TAX. 939, 942-44 (1963) [hereinafter cited as Early].

14 Galvin, The "Onght" and "Is" of Oil-and-Gas Taxation, 73 HARv. L. Rev. 1441, 1501-02 (1960) [hereinafter cited as Galvin].

15 See generally Purchaser.

16 If B's share of production during the payout period does not meet expenses, he must capitalize his added outlay as part of the acquisition cost of his depletive interest. See $i d$. at 970 (quoting text of service ruling so stating). Competent engineering data, however, will usually assure $B$ that his share will equal or exceed his expenses. See $A B C 3$.

17 Trevathan, supra note 6, at 189-91. For examples of rulings, see Purchaser 961. The magnitude of some $A B C$ transactions is best depicted by one notable example. In June 1956, the Atlantic Refining Company acquired oil property from the Houston Oil Company of Texas. Among the assets were 473 oil wells and 977,000 acres of nonproducing mineral properties-properties which required more than 25,000 deeds and more than two million pages of preparation to convey. Atlantic paid approximately $\$ 73,500,000$ cash, and Houston retained two production payments amounting to $\$ 125,000,000$. These payments were payable out of $85 \%$ of the present oil and gas production of the properties. Several intermediate companies immediately paid Houston for the retained production payments. See generally " $A B C$ " or " $X Y Z^{\prime}$ " Private Ruling, 6 OII \& GAS TAX Q. 51 (1956). 
same property is labeled a "carve out." 18 Proceeds received on the sale of such "carve outs" were originally accorded capital gains treatment, but in 1946 the Service took the position that cash received on their sale would be considered a mere anticipation of income. ${ }^{19}$ This would result in the cash being treated as ordinary income subject to depletion. This position was not immediately accepted by the courts, however, and many years of losing court battles passed before the Service finally prevailed in 1958 in Commissioner v. P.G. Lake, Inc. ${ }^{20}$ Although Lake's factual situation dealt with a pure carve out, Mr. Justice Douglas' opinion spoke in broad terms of anticipation of income and did not limit itself to the specific facts of the case. Storm warnings were raised for the ABC when the Service used this broad approach successfully to attack transactions which were not pure carve outs. ${ }^{21}$ Braced by these subsequent victories, the Service suspended ABC rulings on July 17, 1961, and stated that it was considering a possible change in tax treatment. This move generated so much protest, however, that in September of the same year the Service resumed its approval of ABC rulings in "arm's length" transactions between "unrelated parties," with the proviso that further word would be forthcoming. ${ }^{22}$ No additional action has yet been taken. ${ }^{23}$

18 See Schoenbaum, New Legislation, Regulations and Other Recent Developments Affecting the Taxation of Oil and Gas Income, 8 TULANE TAX INST. 338, 351-52 (1959). Definitions are given in MonTGOMERY, op. cit. supra note 1, at 12.44; Bergen, Oil Payments and the Investor, 4 Rocky MT. Mineral L. INST. 87, 94-95 (1958); Simon, Supreme Contrt Says No to Capital Gain Treatment of Carved-out Oil Payments, 37 TAxes 61 (1959).

19 G.C.M. 24849, 1946-1 Cum. BuxL. 66; see Ray \& Hammonds, The Income Tax on Proceeds From the Sale of Oil Payments: The Validity of G.C.M. 24849, 25 Texas L. Rev. 121 (1946).

20356 U.S. 260 (1958). For a complete discussion of the history of the contentions on carve outs, see Benjamin \& Currier, The Supreme Court and Taxation of Oil, Gas and Production Payments: the Lake Cases, 19 LA. L. Rev. 579 (1959); Hammonds \& Ray, Oil Payments Revisited: Current Income Tax Status of Oil Payments, 33 TAxes 349 (1955); More About the Carved-out Oil Payment Controversy, 6 OII \& GAS TAX Q. 231 (1957) ; Simon, supra note 18; 68 HARV. L. REv. 1081 (1955). For a general discussion of the Lake case, see Lyon \& Eustice, supra note 1; McClure, supra note 1; Schoenbaum, stipra note 18, at 351 .

21 E.g., United States v. Foster, 324 F.2d 702 (4th Cir. 1963) ; Jay H. Floyd, $20 \mathrm{CCH}$ Tax Ct. Mem. 303 (1961); O. W. Killam, 33 T.C. 345 (1959); see Lyon \& Eustice, supra note 1, at 67 . See generally. Appleman, The $A B C$ Deal, 11 INsT. OII. \& GAS L. \& TAX. 519, 529 (1960) [hereinafter cited as ABC Deal]; Bullion, Production Payment Transactions-Recent Developments, 6 Rockx MT. MINERAL L. INsr. 81 (1961); Soter, Taxation of Oil and Gas Financing Arrangements, 31 U. CINC. L. Rev. 1 (1962); Oil Payment Developments-Post P.G. Lake, 9 OII \& GAs. TAX Q. $133(1960)$.

$22 \mathrm{~B}$ will not presently qualify for $\mathrm{ABC}$ treatment if he forms an alter ego corporation $C$; furthermore, if $A$ forms a corporation to act as $B$, the Service will treat the transfer of the production payment to $C$ as a carve out. Montgomery, op. cit. supra note 1 . Favorable rulings are also unavailable where the parties possess a $\$ 318$ type relation in the most general way. The degree or percent of such relation deemed critical varies from situation to situation. ABC Deal 556; Current $A B C$ Matters, 13 OII \& GAS TAX Q. 43 (1963); IRS Technical Information Release No. 338, Sept. 1961. It further appears that the Service will not issue any rulings on $A B C$ 's where there are elements present which differ from those in prior favorable rulings. Purchaser 962 .

23 One tax accounting firm has promulgated five rules to follow to obtain favorable rulings. These are: (1) all negotiations must be bona fide and at arm's length; 


\section{B. Criticism of the $A B C$}

The present tax treatment of the $A B C$ may be questioned on several grounds. The treatment of $A$ may be criticized because of the plan by which he splits and sells his leasehold to obtain capital gains. That of $B$ may be attacked because he is able to exclude production proceeds from his income, even though he would have to include them under a mortgaged purchase. The taxation of $\mathrm{C}$ may be challenged because his role in the $A B C$ more closely resembles that of a lender than of an actual investor in the oil in place.

This Comment will examine the economic structure of the $A B C$ and will suggest changes in the present tax treatment of the transaction. Special emphasis will be placed upon the theories underlying the tax treatment of each participant, since the tax consequences of the transaction for any party are greatly affected by the manner in which the roles of the others are classified for tax purposes. Thus, if $\mathrm{A}$ were not considered as making a sale when he divides his leasehold and conveys to both $B$ and $\mathrm{C}, \mathrm{B}$ would be forced to buy the entire leasehold to secure capital gains for $A$ on the full purchase price. This would force $B$ into a purchase-mortgage transaction, and change his tax treatment. Similarly, if C's possession of the production payment were not classified as an economic interest, the proceeds of that payment would be attributed to $\mathrm{B}$ because of his ownership of the underlying leasehold. This would also alter B's tax treatment.

\section{An Analysis of the ABC Transaction}

\section{A. The Taxation of $A$}

Although completed simultaneously, there are two separate transactions in the $A B C$. These are the transfer of the leasehold to $B$ subject to the retained production payment, and the subsequent conveyance of the production payment to $\mathrm{C}$.

\section{Transfer of the Leasehold to B With A Retaining the Production Payment}

Under current tax treatment, if A transfers a leasehold and retains only a limited oil payment, he is considered to have made a sale and the cash received is therefore accorded capital gains treatment. On the other

(2) the working interest must be disposed of prior to or simultaneously with the sale of the oil payment; (3) the oil payment should not be so large in proportion to the estimated recoverable reserves that it takes on the character of a reserved royalty; (4) the purchaser of the working interest should receive a sufficient percentage of the production to cover expenses; and (5) the production payment must be a bona fide economic interest, i.e., must be payable solely out of the proceeds from the sale of the production of the property. NAturad. Resources Staff, Artaur Anderson \& Co., OIl and Gas Federal Income Tax Manual 313 (8th ed. 1960). 
hand, if $\mathrm{A}$ assigns the operating rights to his leasehold for cash, and reserves an interest which will continue for the life of the lease (such as an overriding royalty or a net profits interest), the transaction is considered a sublease and the cash received is treated as an advance royalty bonus. The 200,000 dollars would thus have been classified as depletable ordinary income. ${ }^{24}$ Although A might later sell the retained royalty for 800,000 dollars-thus giving him the same one million dollars for his holdingsonly the 800,000 dollars would be accorded capital gains. The salesublease distinction, which accounts for this varying treatment of the 200,000 dollars cash, turns upon the nature of the interest retained by $\mathrm{A}$. If the retained interest is a continuing one, the transaction is considered a sublease; if noncontinuing, a sale. ${ }^{25}$ Since the oil payment does not continue for the full life of the property, the A-B transaction is classified as a sale, and $\mathrm{A}$ receives capital gains. The sale-sublease distinction thus enables $A$ to retain a substantial interest in the property and still receive capital gains on the transfer of the underlying leasehold. ${ }^{26}$ That the classification of the A-B transaction as a sale should not rest upon the mere noncontinuity of $A$ 's interest is emphasized by these benefits $A$ receives.

Whether there has been a "sale" for purposes of the capital gains provisions of the Code depends upon whether there has been an outright conversion of the vendor's property for a fixed price. Viewed from a different perspective, a "sale" is a transaction by which an investor concludes his investment and thereby establishes its success or failure by "cashing it in" for its present worth. ${ }^{27}$ In this context, the vendor's reservation of a production payment might profitably be compared to the retention of a royalty. ${ }^{28}$ Retaining a royalty would continue A's investment for the life of the leasehold by guaranteeing him a share of any benefits which might later accrue. On the other hand, a seller who retains a production payment holds an interest which will not continue for the life of the property; consequently, he can be considered as relinquishing any other benefits-such as underestimated reserves-which the lease might hold. Although the vendor thus loses some valuable incidents of his investment, the question of whether there has been a complete divestment for purposes of capital gains is not thereby fully resolved. ${ }^{29}$ That

24 Palmer v. Bender, 287 U.S. 551 (1933).

25 See Cullen v. Commissioner, 118 F.2d 651 (5th Cir. 1941); Commissioner v. Fleming, 82 F.2d 324 (5th Cir. 1936).

26 Section 1245 of the 1954 Code may convert some of the gains into ordinary income, however. Seller 974 n.3.

27 SURREY \& WARREN, op. cit. supra note 12, at 770.

28 "A royalty is an interest in oil which entitles its holder to a share in the proceeds of the oil produced as long as there is production without. . being charged with the cost of development or operation." Note, 104 U. PA. L. REv. 1088 n.6 (1956).

29 Bullion, supra note 21 , at $94-96$, gives an example of another situation in which complete divestment may be necessary for a sale. Suppose $A$ sells his leasehold to $B$ for one million dollars and $B$ agrees that after a specified payout new 
question-and with it the question whether there has been a "sale"would appear to turn instead on the nature of the production payment itself. More specifically, is the payment actually a reservation of oil or is it merely a right to a specific amount of money?

It has been argued that the current "sale" classification of the A-B transaction is justified because the production payment is essentially a reservation of oil. A is therefore viewed as selling only part of his oil holdings and retaining the balance. This reasoning, however, is inconsistent. As noted above, a sale qualifying for capital gains treatment results in a complete divestment for a present value. If it is decided that the production payment is essentially a reservation of oil, with the holder assuming real risks of ownership, it would follow that $A$ has not made a sale of the leasehold, since he has retained a stake in the property. Dependent upon future production for the ultimate return of his original investment, he should not be considered as making the required divestment. Only a classification of the production payment as a right to a fixed sum of money would be consistent with the concept of sale. Such a classification would view $\mathrm{A}$ as limiting his return to a current figure-the amount of the payment plus the sum of the cash-and thus as converting his asset at a present worth. This view seems more consonant with the economic substance of the transaction.

In Commissioner $v$. Fleming, ${ }^{30}$ one of the early cases announcing the sale doctrine, the Fifth Circuit stated that "it is true . . . that the reservation was limited not to so many barrels nor to such a length of time, but to so much oil as would sell for the agreed sum. But it was in effect an exception or reservation of oil." Such a conclusion overlooks the fact that the sole relationship of the production payment to the oil in place is the payment's dependence upon oil production for its value. True ownership of the oil in place would consist of ownership of a certain percentage of oil for the life of the market. Although this incident of ownership is retained by the holder of a leasehold or royalty interest, the set, limited amount of the production payment deprives its holder of this ownership feature. If the payment were a true reservation of oil, $\mathrm{A}$ and $\mathrm{B}$ would each own a certain number of the estimated barrels in place after the reservation, and those barrels would then be subject to varying market prices. If the price of oil subsequently rose, each owner's return on his investment would then be increased because the proportional worth of each barrel would go up; if the price of oil were to decrease, each owner's

engineering estimates will be made and a new consideration will be paid to $A$ on the basis of such estimates. Bullion notes that the Service ruled, even after Lake, that $A$ was entitled to capital gains on both the one million dollars and the added consideration, but that the Service is presently holding back such rulings. $\mathrm{He}$ questions this rethinking, since $A$ has disposed of his entire depletable interest in this initial transaction, and thus under I.T. 4003, 1950-1 CUM. BuLL. 10, should be accorded capital gains. Viewing the problem as requiring an initial divestment, however, could settle the question.

3082 F.2d 324, 327 (5th Cir. 1936). 
return per barrel would also decrease. To equate the production payment with ownership of a portion of the oil in place introduces the anomaly of shifting ownership, since if the price of oil rises, the number of estimated barrels owned by A decreases while B's total increases. Nor does the formalistic contention that the ownership in question is ownership of "so much oil as would sell for the agreed sum" seem to meet this problem adequately.

Reinforcing the conclusion that the production payment does not constitute ownership of the oil in place is the fact that its payout is quite certain, and therefore that the vendor has cashed in his investment without running any significant risk that his contracted return will be affected by the future of the leasehold. In actual practice, the $A B C$ is grounded upon this certainty; if it were otherwise, the deal would not be consummated. ${ }^{31}$ The use of modern scientific methods to estimate the oil reserves in a specific property, and the availability of advanced techniques to assure maximum recovery, make the potential yield the subject of close approximation..$^{32}$ Further assurance that the oil payment will completely pay out is supplied by the customary insistance of the financing bank that the payment terminate far short of estimated reserves so that its security will be protected. It thus seems reasonable to conclude that the production payment is, in the words of the Lake case, "ascertained with considerable accuracy" and almost certain to pay out.33

Further support for treating the production payment as a right to a definite sum of money is given by the economic position of $A$ after assignment of the leasehold. The money he would receive each year under the terms of the production payment is ordinary income. He has neither a reversion after receiving the contracted income, nor any right either to control the amount of income to be produced from the land or to decide whether the land should be used for other income producing purposes. Since he is unaffected by the market place and has a right to draw a definite amount of income from regularly producing wells, he is subject to little risk. The only actual "ownership" risk which he bears is the risk of insufficient production and this is factually unlikely. Thus, if the tax law is to fulfill its function of dealing in economic realities and not in legal abstractions, ${ }^{34}$ it should consider the owner of the production payment as holding a mere right to receive income and not as being the owner of the oil in place.

As stated above, by viewing the production payment as a right to a definite amount of money, A can be considered to have converted his asset for present worth-the cash plus the amount of the payment. Unlike

31 Early 944.

32 See Welsch, Acquiring Properties Through Oil Payments and Related Methods, 32 TAXes 494 (1954). For a brief description of the type of procedure used in oil discovery, see Galvin 1479-81.

33 Commissioner v. P. G. Lake, Inc., 356 U. S. 260, 265 (1958).

34 Commissioner v. Southwest Exploration Co., 350 U.S. 308, 315 (1956). 
the situation in which the vendor retains an overriding royalty which will continue for the life of the lease, $\mathrm{A}$ has settled for a total present realization of the value of his leasehold and may therefore be treated as having made a sale. In such a situation the A-B transaction may be considered as a credit sale to $B$, with the cash constituting a down payment and the production payment being an account receivable. A would then be in the position of a mortgagee without a bond or of a creditor who may not look to the personal liability of the debtor but must look instead to a particular fund for his payment. A could avoid the problem of having to declare the total amount of the payment in the year of sale by using the installment method of accounting. Aithough the foregoing analysis retains the well settled sale doctrine, it reaches this result under a more economically accurate rationale. Only within this context is the sale result warranted.

\section{Transfer of the Production Payment to $\mathrm{C}$}

The second transaction in the $A B C$ is A's conveyance of the reserved production payment to $C$. As discussed above the current reasoning supporting a "sale" result in the $A B C$ rests upon the theory that $A$ has reserved a quantity of oil. If the $A B C$ is to be considered a credit transaction with respect to $B$, however, it should also be considered a credit transaction with respect to $C$. Adoption of such an approach requires a rejection of the current theories relating to the A-C transaction.

Four major defenses have been advanced in favor of the current capital gains treatment of the A-C conveyance. ${ }^{35}$ It has been argued that: (1) the production payment is property for purposes of section 1231 and therefore a capital asset entitled to capital gains when sold; ${ }^{36}$ (2) since the production payment is the entire depletable interest which $A$ owns, he is entitled to capital gains upon its sale; (3) regardless of the label placed upon the payment, $\mathrm{A}$ has in two related transactions disposed of the whole of a leasehold which was itself a capital asset, and therefore should be accorded capital gains under the "step transaction" or "net effect" doctrine; and (4) since A could undoubtedly have obtained capital gains by conveying the entire leasehold to $C$, with $C$ then transferring the leasehold to $B$ subject to the oil payment, A should not be denied capital gains for following the slightly different $\mathrm{A}-\mathrm{B}-\mathrm{C}$ route.

\section{a. Capital Asset Argument}

There are several arguments to support the proposition that the production payment is a capital asset. It is asserted that the Internal Revenue

$35 A B C$ 1-3.

36 It might also be possible to classify the payment as an investment in real property within the definition of $\$ 1221$ of the 1954 Code. As the holder of the payment, A could be viewed as having invested in the right to receive income created by another, and his gain could be seen as derived from this sale of a right which he held for investment. The Supreme Court, 1957 Term, 72 Harv. L. Rev. 77, 114 (1958). 
Service has recognized that it is property in many contexts: it has a basis ${ }^{37}$ it has been held to be property of unlike kind when exchanged for a royalty, ${ }^{38}$ for a working interest and a royalty, ${ }^{39}$ or for a working interest only $;^{40}$ and a deduction has been permitted when it becomes worthless. ${ }^{41}$ Moreover, the Service has held that a transfer of a retained production payment in an $A B C$ transaction is subject to a documentary stamp tax as a conveyance of realty. ${ }^{42}$ Even if it is granted that the oil payment is "property" in a general tax sense, however, it does not follow that it is "property" for purposes of the capital gains section. The problem has been stated well by Professors Surrey and Warren:

A consideration of the problems created by the all-inclusive scope of "property" in the statutory definition of capital asset leads to . . [a] source of difficulty. Congress as respects capital gains presumably had in mind a distinction between recurring receipts such as salaries, wages, interest, rents, dividends, royalties, and the like on the one hand and the nonrecurrent realization of the appreciation in the value of property on the other . . . [T] [Te right to a salary earned, or to interest accrued, or a dividend due, is "property" in the legal sense. Does such a right when sold, therefore, transport the salary, interest, or dividend out of the ordinary income area and into the capital gain category via the term "property" in the definition of capital assets? ${ }^{43}$

The capital asset argument would thus appear inconclusive.

\section{b. Disposal of the Entire Depletable Interest}

It has also been argued that $A$ is entitled to capital gains because the $A B C$ transaction disposes of his entire depletable interest in the property. This view is based upon Revenue Ruling I.T. 4003,44 which established a general rule that:

the assignment of any in-oil payment right (not pledged for development), which extends over a period less than the life of the depletable property interest from which it is carved, is essentially

37 See, e.g., Commissioner v. Laird, 91 F.2d 498 (5th Cir. 1937).

38 Midfield Oil Co., 39 B.T.A. 1154 (1939).

39 Kay Kimbell, 41 B.T.A. 940 (1940).

40 Bandini Petroleum Co., 10 CCH Tax Ct. Mem. 999 (1951).

41 Louisiana Iron \& Supply Co., 44 B.T.A. 1244 (1941).

42 Rev. Rul. 59-282, 1959-2 Cun. Burc. 332. For private rulings on this issue, see Doctmentary Stamp Tax Status of Oil Payments, 6 OII \& GAS TAX Q. 181 (1957).

43 SURREY \& WARREN, op. cit. supra note 12, at 770.

44 1950-1 Cum. Bull. 10, 11. 
the assignment of expected income from such property interest. Therefore, the assignment for a consideration of any such in-oil payment right results in the receipt of ordinary income by the assignor. . . .

Although this rule would disqualify A from receiving capital gains on the assignment of the production payment to $\mathrm{C}$, the ruling established a weighty exception-the above rule did not apply "where the assigned in-oil payment right constitutes the entire depletable interest of the assignor in the property. . . ." 45 In Commissioner v. P. G. Lake, Inc., ${ }^{46}$ the Supreme Court cited the above ruling as representing "the present view of the Commissioner." Some writers have interpreted this reference as an expression of judicial approval of the ruling, and therefore as authority for granting A capital gains in his transaction with $C .47$ This conclusion, however, overlooks the simple fact that the reference purports to do nothing more than to supply information, and thus cannot be considered as approving a capital gains theory. That the Supreme Court did not intend its passing reference to support such a theory is also indicated by its addition of a caveat that "prior administrative practice is always subject to change "through exercise by the administrative agency of its continuing rule making power." " 48

It might also be argued that McAllister $v$. Commissioner ${ }^{49}$ supports a capital gains treatment of the A-C transaction, irrespective of the character of the production payment. The taxpayer in that case had sold her life income interest in a trust. Contending that this life interest was a capital asset, she deducted a capital loss on her return. Although the Commissioner asserted that the entire sales price should be ordinary income, the court held with the taxpayer, reasoning that the transfer of an entire interest in a right to receive future income should be accorded a capital gain or loss. ${ }^{50}$ In reaching their result, the majority in McAllister stated that "the distinction seems logically and practically to turn upon anticipation of income payments over a reasonably short period of time and an out and out transfer of a substantial and durable property interest, such as a life estate at least is." 51 Even if this substantial versus insub-

$45 \mathrm{Id}$. at 11 . (Emphasis added.)

46356 U.S. 260,265 n.5 (1958).

47 $A B C$ 12-13. Appleman presses even further by stating that "the Lake decision simply sustains the position of the Service, which position included recognition of the ABC deal." $A B C$ Deal 530 .

48356 U.S. at 265,266 n.5.

49157 F.2d 235 (2d Cir. 1946).

50 See SuRrey ANd Warren, op. cit. supra note 12, at 773.

51157 F.2d at 237. 
stantial distinction were accepted, ${ }^{62}$ it is by no means applicable to the $A B C$ transaction. Although a life estate, because of its length and its indefiniteness, might be considered substantial, it certainly does not follow that a limited production payment should also be so classified. The sale of a royalty, which continues for the life of the property, would appear more analogous. Thus, neither the entire depletable interest argument nor the McAllister decision settle the question of whether $\mathrm{A}$ should receive capital gains on his transaction with $\mathrm{C}$.

\section{c. The Step Transaction Doctrine}

A much more persuasive argument for capital gains treatment is based upon the so-called step transaction doctrine. It has been said that "the government and taxpayers alike have long accepted the simple mathematical equation that a simultaneous assignment of two parts comprising the whole is equal to a single assignment of the whole." 53 If A can receive capital gains on the sale of his entire leasehold to one person, it is argued that he should receive similar treatment when he converts the leasehold in two related or simultaneous transactions. Such an argument rests upon the undoubtedly true proposition that the vendor in a contemporaneous sale has all the property one minute, and all the cash the next. ${ }^{54}$

Although this net effect doctrine is not easily refuted, it may not necessarily be controlling if $\mathrm{A}$ disposes of his entire interest in an incorrect manner. For example, if $A$ had separated his leasehold into two undivided interests and had sold them to two different people, capital gains would seem to be in order. Under present law a similar result would occur if A first sold a royalty and then subsequently disposed of the leasehold.55 However, if A retains a royalty on the transfer of the leasehold to B (now considered a sublease transaction) and then transfers that royalty to $C$, a different problem is presented. Should the "net effect" doctrine convert the prior sublease with its resultant ordinary income into a capital gains transaction? ${ }^{56}$ Moreover, if $\mathrm{A}$ carves out an oil payment and then sub-

62 In a strong dissent, Judge Frank certainly did not accept it:

Congress believed that the exaction of income tax on the usual basis on gains resulting from dispositions of capital investments would undesirably deter such dispositions ....

...

I think it most unlikely that Congress intended by... [the capital gains provisions] to relieve such a taxpayer of the ordinary tax burdens, to supply an incentive for the demolition of such a trust.

Id. at $239,241$.

$53 A B C 5$.

64 ABC Deal 529.

55 See Galvin 1499.

50 Appleman would say that it should :

In an $A B C$ deal, however, in the author's opinion, it should make no difference, so far as $A$ is concerned, if the so-called oil payment interest is 
sequently sells the leasehold, would the latter conveyance relate back to convert the proceeds from the carve out into capital gains? ${ }^{57}$ It is doubtful that the Internal Revenue Service would recognize such results. These examples demonstrate that the step transaction doctrine provides a satisfactory rationale for classifying the A-C transaction as a capital gains transaction only if one is willing to concede that the type of interest initially retained by $A$ should not be important so long as he sells the entire leasehold in related transactions. If one cannot accept this proposition, the problem posed by the transaction is left unsettled.

\section{d. The A-C-B Alternative}

A final argument for capital gains is that $A$ could have conveyed the entire leasehold to $\mathrm{C}$-undoubtedly a capital gains transaction-and $\mathrm{C}$ could then have transferred the leasehold to $B$ subject to the reservation. Since A could have followed an A-C-B route, it is argued, he should not be penalized for following an A-B-C one. ${ }^{58}$ It does not follow, however, that because A could have obtained capital gains by one method he should be awarded them even if he pursues another. Moreover, in the A-C-B scheme, $C$ would be in the shoes of $A$ and thus subject to all of the criticisms of the A-C transaction made above.

\section{e. Taxing the A-C Transaction}

In sum, it would appear that the current arguments advanced for capital gains treatment of A-C transaction are at best inconclusive, and persuasive counterarguments can be made. A more reasonable approach to the problem of whether this transaction should be accorded capital gains treatment is to adopt a test which considers the character of the particular interest sold.

Viewing the payment as a reservation of oil, some writers would attempt to solve the capital gains issue by imposing upon the transaction the famed tree-fruit structure enunciated by $\mathrm{Mr}$. Justice Holmes in Lucas v. Earl.59 The argument is that the allowance for depletion on the payment is tacit recognition that part of the tree (the leasehold) was retained with the production payment and therefore that capital gains

in fact an overriding royalty interest, for the reason that $A$, in substance as well as in intent, has made a sale of all his interest in the property, albeit to two parties, and not a sublease. It is doubtful if the Service would so rule, but it is believed the Courts would so hold.

Seller 973, 976.

57 See $A B C$ Deal 528 . The importance of employing the proper sequence in the $A B C$ transaction to avoid the possibility of inadvertently creating ordinary income is noted by Galvin, at 1501 n.187.

58 See $A B C$ 16. A might also transfer the entire leasehold to $\mathrm{X}$ who in turn would convey the working interest to $B$ and a reserved production payment to $C$. See $A B C$ Deal 537 n.30.

59281 U.S. 111, 115 (1930). 
should be given on its sale. ${ }^{60}$ It would seem, however, that a method by which capital is returned tax free should not necessarily denote the existence of a tree in the tree-fruit sense. ${ }^{61}$ Moreover, the concept that A disposed of the tree on the transfer of the leasehold to $B$, and retained only the fruit which was then conveyed to $C$ would seem to square equally well with the Holmes metaphor.

On the other hand, if the production payment is viewed as a right to a specific amount of ordinary income, the A-C transaction could be considered as a mere anticipation of income, ${ }^{62}$ rather than as the conversion of a capital asset. If the sale of a presently accrued right to income is not to be accorded capital gains, it might fairly be argued that the sale of a right to receive income in the future, when that income is relatively certain, should not be a capital gains transaction either. ${ }^{63}$ The Lake case lends support to such a view since it holds that the sale of a production payment where its payout is certain can bring ordinary income, regardless of property concepts. Nor is this approach answered by arguing that the value of the payment, like that of any other income producing property, reflects some anticipated future income to be derived from it, ${ }^{64}$ for such an argument ignores the fact that the particular property involved in the A-C transaction does not represent an economic value devoted to the production of income, but is itself the product.

These problems can be avoided, however, if the A-C conveyance is conceptually integrated with the credit sale treatment of the A-B transaction. This would be accomplished, as discussed above, by viewing the A-B transaction as a credit sale and the oil payment as an account receivable. Under such an appoach the A-C conveyance would be viewed as an assignment for cash of an account receivable. By employing this framework, the well-established sale result of the A-B transaction is preserved, and $A$ retains his capital gains, a sound although not necessary result since he has disposed of his entire property interest. The only change is to substitute new reasons for reaching these results in order to square the tax theory with the economic substance of the $A B C$ transaction.

${ }^{60} A B C 9$ n.16a.

61 Ernest Brown has written this of Holmes' metaphor :

It is this apparently innocent figure of speech which has given to the judicial law of deflected income a distinctly horticultural flavor. . . . Judges perhaps more at home with common law ideas than Revenue Acts have turned to search for a property concept which could constitute a tree capable of being transplanted. If they could discover an income-producing property "tree," capable of being transplanted and which had been transplanted or transferred, then the deflection was successful. If no tree or no transplant, then no deflection.

Brown, The Growing "Common Law" of Taxation, 1961 U. So. CAL. TAX INST. 1, 15. 62 See Note, Distinguishing Ordinary Income From Capital Gain Where Rights to Future Income Are Sold, 69 HARv. L. Rev. 737 (1956).

83 The Supreme Court, 1957 Term, 72 HARv. L. Rev. 77, 113 (1958).

64 See Surrey, Definitional Problems in Capital Gains Taxation, 69 Harv. L. Rev. 985, 1003-04 (1956). 


\section{B. The Taxation of $B^{65}$}

Since his gross income will be reduced by the full amount of the production payment, $\mathrm{B}$ profits the most from the $\mathrm{ABC}$ transaction. ${ }^{66}$ Even under current tax treatment, however, $B$ will lose this right to exclude the proceeds from his income if he guarantees that $\mathrm{C}$ will obtain the full amount of the payment. If any such personal liability is found running from $\mathrm{B}$ to $\mathrm{C}, \mathrm{C}$ will be held not to have an economic interest and $\mathrm{B}$ will have to declare as ordinary income all the proceeds allocated to the payment. ${ }^{6 \tau}$ The Internal Revenue Service treats such transactions as mere debt obligations. C's interest is found not to be a "true" production payment, since the latter is a payment whose return is "derived solely from the production of oil and gas." ${ }^{8}$ The existence of any other source

65 See Minyard, How To Determine the Tax Saving That Makes an ABC Deal Worthwhile, 12 J. TAXATION 290, 291-92 (1960); Purchaser 957-58.

68 Rowen calculates B's maximum tax advantages in the following manner:

(1) B's gross income while the production payment pays out will be reduced by the full amount of the production payment.

(2) Assuming that B employs percentage depletion, the exclusion of the amount of the production payment from $B^{\prime}$ s gross income will reduce his percentage depletion deduction by $27 \mathrm{~s} / 2 \%$ of the amount of the production payment.

(3) The net result of (1) and (2) is that B's taxable income from the property is reduced by $725 \% 2 \%$ of the amount of the production payment.

(4) Assuming a $50 \%$ tax rate, this means that $B$ will save $37 \% / 4$ cents ( $1 / 2$ of $721 / 2$ cents) in taxes for every dollar of A's selling price that is represented by the production payment.

In actual practice, $B$ 's tax advantage from the $A B C$ transaction will not be so great.

First, the effect of the interest factor in the production payment, which has been disregarded in the above computations, is to reduce the advantage of the $A B C$ transaction. Thus, if $B$ purchased the property in the conventional manner with the proceeds of a bank loan, the interest would be deductable and would not reduce B's gross income for depletion purposes. Under the $A B C$ transaction the interest factor is wholly excluded from B's gross income, and B thereby loses the benefit of percentage depletion on the interest factor. The total tax detriment to $B$, assuming a $50 \%$ tax rate, comes to $133 / 4$ cents on each dollar of "interest factor" that is paid. If the "interest factor" were very high and the production payment did not pay out for an unusually long time, this detriment might offset the benefit from the ABC transaction, but in most cases the effect is relatively small.

Second, if the expected production from the property is such that B's cost depletion would exceed percentage depletion if $B$ acquired the property by a conventional purchase, B's tax saving will be somewhat less than computed above, but it would still be substantial in the early years.

Third, owing to the $50 \%$ of net income limitation, B ordinarily would not obtain the full benefit of percentage depletion on B's share of the income during the period of payout of the production payment.

Purchaser 960-61.

67 Anderson v. Helvering, 310 U.S. 404 (1940); Purchaser at 964.

68 Anderson v. Helvering, supra note 67, at 413; $A B C$ 18-19. Appleman found that on a sample $A B C$, over a seven year period, $B$ made approximately a $45 \%$ return of investment through the $\mathrm{ABC}$ and only $20 \%$ without it (the sample $\mathrm{B}$ was in the $80 \%$ Bracket). Moreover, the larger the payment, the greater the return and the less the risk. $A B C$ Deal 523-26. 
of payment, such as a guarantee, nullifies this characteristic and deprives $B$ of the benefits ordinarily granted him under the $A B C .^{69}$

Since B depends upon C's purchase, he may attempt to provide some alternative to a guarantee to pursuade $\mathrm{C}$ to purchase the oil payment. Several roundabout methods might be employed. One such method is the guaranteed market. Although reserves can be estimated, future prices cannot. Thus, to protect $\mathrm{C}$ against a drop in price, $\mathrm{B}$ may agree to purchase the oil and gas at a fixed price. ${ }^{70}$ Such an approach, however, would not protect $C$ if the oil reserves should run unexpectedly low or if the well should run dry. To meet these problems, B might take an option to purchase the production payment at a fixed price. ${ }^{71}$ Should production then terminate, $B$ will purchase the oil payment, thus allowing $C$. to regain his investment. To avoid these problems altogether, B might establish a dummy corporation to perform C's function. The corporation would borrow the needed funds from a bank, and $\mathrm{B}$ would then obligate himself to purchase its note in the event of a default. The last, and easiest, method would be to make a simple under the table reimbursement.

Under a standard which requires a "true" production payment to be "derived solely from the production of oil and gas," none of these plans is satisfactory. Thus if any of these methods is employed, the payment should not be treated as an independent interest. If $C$ is to be considered as a true owner, he should be required to bear all of the incidental risks of ownership.

There are two principal theories which the Internal Revenue Service might employ to attack B's position under the ABC. To begin with, it could treat $B$ as having bought all of the leasehold from $A$, and then as having made a carve out of the oil payment to $C$. The second possibility would be to treat the production payment as a mortgage debt for tax purposes. This would be the same theory proposed earlier. Under this

69 Anderson v. Helvering, 310 U.S. 404 (1940); Galvin 1501. It might be questioned whether the mere possibility that C could look to some of B's assets (as opposed to a direct alternative source of payment) should make the production payment a debt. In the Anderson case, it was held that a reservation of a fee interest in the property in addition to the interest in the payment nullified the independent interest. The Court said, 310 U.S. at 412 , that the interest was not "dependent entirely upon the production of oil for the deferred payments," because some of the deferred payments might have been derived from sales of the fee title to the land conveyed. Anderson would therefore suggest that the mere possibility of another source would destroy the validity of the payment. Subsequent cases in the hard mineral industry seem to support an independent interest, however, where terms provided for the possibility of other sources. See Myers v. Commissioner, 11 T.C. 495 (1948); Herndon Drilling Co. v. Commissioner, 6 T.C. 628 (1946). This problem might be avoided if it is reasonably expected that the payment will be liquidated solely from oil and gas. However, it would still probably be advisable to heed Anderson. See generally The Guaranteed Production Payment Dilemma, 14 OII \& GAS TAX Q. 1 (1964).

70 Welsch, supra note 32, at 500. Rowen states that the Service has given indications that, as long as the fixed price is not unreasonable, it would approve a transaction with such a guarantee. There have been no rulings, however. Purchaser 967.

71 Welsch, sutpra note 32 , at 500 . 
approach, $B$ would be obliged to capitalize the amount of the payment as an extra cost of acquiring the property and would be unable to exclude the proceeds from his income. The effect of this would be to disqualify the production payment as a separate property interest. ${ }^{72}$

\section{The Carve Out Approach}

The applicability of the carve out theory turns upon whether the oil payment would fall within the boundaries defining a carve out. A 1963 Fifth Circuit case established the rule that an oil payment which was carved from a depletable property and which had a payout which could be predicted with reasonable accuracy when it was sold, would be designated a carve out. ${ }^{73}$ Since the economic viability of the $A B C$ depends upon the certain payout of C's interest, this rule could easily be applied to the $A B C$ transaction.

If the carve out theory were adopted, a serious problem of when to $\operatorname{tax} B$ on the attributed income would arise. If $B$ is to be considered as making a carve out to $C$, it might be argued that $C$ 's purchase price should be treated for tax purposes as received by $B$, and that $B$ consequently should be considered as receiving presently realized income. Lake supports such an argument, since it held that the income obtained on the assignment of the carve out was taxable when received (here the year in which $C$ would pay $A$ for the oil payment.) ${ }^{74}$ If this result were adopted, B's income would be bunched undesirably into one year, with a tax being placed upon income which $B$ would not receive under any other theory until later. Under an ordinary cash purchase, on the other hand, $\mathrm{B}$ would be taxed only as the oil was produced.

\section{The Mortgage-Loan Theory}

The mortgage-loan theory would treat B as if he had gone to a bank, borrowed the needed funds, mortgaged all the oil and gas property, and then repaid the loan out of income from the property. ${ }^{75} \mathrm{~B}$ would then be a mortgagor and $\mathrm{C}$ a mortgagee. Since $\mathrm{B}$ had no personal liability in the $A B C$, it is perhaps more precise to liken $C$ to a secured lender-creditor who looks only to the production payment for his recovery. ${ }^{76}$

72 Purchaser 962.

73 United States v. Foster, 324 F.2d 702, 707-08 (5th Cir. 1963).

74 Commissioner v. Lake, 356 U.S. 260 (1958). The fact that Lake held the amount received to be depletable income is not inconsistent with the loan approach, because the conclusion in that case stemmed from a premise which is inapplicable to the loan situation-that proceeds received on the sale of a carve out constitute a mere anticipation of income. Id. at 265-66.

75 See $A B C$ 19-20. The loan concept was generated to a large extent by Commissioner v. Slagter, 238 F.2d 901 (7th Cir. 1956), in which an undivided share in operating interests was assigned until the assignees received a sum of money which was net of costs and expenses. When that occurred, the interests were to revert to the assignors. It was held that the transaction resembled a nonpersonal loan in which the assigned share was pledged to secure the sums advanced, and that the assignors realized income as the loan was repaid. But cf. Estate of Weinert v. Commissioner, 294 F.2d 750 (5th Cir. 1961).

76 Lyon \& Eustice, Assignment of Income: Fruit and Tree as Irrigated by the P. G. Lake Case, 14 So. CAL. TAx Inst. 47, 71 (1962). B's capitalization of the 
Many distinguishing features have been advanced in an attempt to demonstrate that the mortgage-loan theory would be inadequate. ${ }^{77}$ It has been pointed out that the debtor is personally liable in a typical mortgage situation and that liens attach to the entire property, while in the $A B C$, $B$ is not personally liable and liens do not attach to his interests. ${ }^{78}$ These features, however, are not essential for the existence of a valid debt. Debts payable in a special way, or from restricted funds, have been held to be valid obligations. ${ }^{79}$ Moreover, the fact that a lender could look only to a pledged security and not to a personal liability for repayment has been found sufficient to support the validity of loans in the related area of deductions for bad debts. ${ }^{80}$ Finally, mortgages unsupported by personal obligations have been found to create valid indebtedness. ${ }^{81}$ C's willingness to look only to the production payment should not void the debt classification. Indeed, as a practical matter, the existence of this limited security loses all significance if it can be shown that $B$ induced $C$ to settle for it on the basis of a strong certainty of payout. ${ }^{82}$

production payment might produce an unusual tax result in the following situation. Assume that $B$ purchases the leasehold for one million dollars and $C$ the oil payment for four million dollars. A fire then occurs in one of the wells, resulting in a complete loss. The question arises whether $B$ should be able to deduct five million dollars since he capitalized the oil payment, even though his out of pocket loss was only one million dollars, and whether $C$ is entitled to deduct four million dollars in losses since his assets also perished in the fire. One authority has contended that the mortgage theory would permit a "double loss deduction" in such a situation. Id. at 23-24. This conclusion apparently assumes that use of a mortgage-loan theory for purposes of income attribution necessarily binds the Service to that theory to resolve legal ownership for purposes of computing loss deductions. Such is not the case: loss deductions should only be allowed for economic losses suffered by the taxpayer. Thus, in the above situation, $B$ should only be allowed to deduct his one million dollar payment for the leasehold, and $\mathrm{C}$ should be accorded a four million dollar loss deduction.

77 See $A B C$ 22-23.

78 Benjamine \& Currier, The Supreme Contrt and Taxation of Oil, Gas and Production Payments: The Lake Cases, 19 LA. L. Rev. 579, 610 (1959). Appleman maintains the fact that the financing institution possessed a lien on all the property should not alter the result in the $A B C$ as long as $C$ is limited to the production payment for his security. In support of this contention he offers the following example: $A$ owns a lease worth two million dollars, and $B$ wishes to buy it through the $A B C$. A bank will finance the production payment to the extent of $\$ 1,250,000$, but wants liens on all the property. B purchases the working interest subject to the debt and mortgage and $A$ reserves an oil payment for $\$ 1,250,000$. A then sells the reserved payment to $C$, who assumes the debt and releases $A$. The bank now has a mortgage to secure a debt. $A B C$ Deal 553-54. But see Crane v. Commissioner, 331 U.S. 1 (1947) (indicating the debt might be attributed to $B$ and the discharge be taxable income to $\mathrm{him}$ ).

795 Mertens, Federal Income Taxation $\$ 30.03$, at 17-18 (1964).

80 Ibid.

81 See Tanenbaum, The ABC Technique of Financing Real Estate Acquisitions: The Tax Motivated Leasehold, 111 U. PA. L. REv. 161, 164 (1962): "One possible distinction between the ordinary purchase money mortgage transaction and the ABC acquisition is the absence of a personal obligation from $B$ to $C$ in the latter. However, while mortgages often do include such an obligation, it is not uncommon for the bond obligee to be a straw party; some mortgages do not even include a bond. In either of these events, C's remedy realistically is limited to the value of the property itself by enforcement of the mortgage lien, as is somewhat the case in the ABC situation."

82 Ibid. 
Another argument against the mortgage-loan theory focuses on C's separate liability for the taxes and expenses attributable to ownership of the oil payment. This incident of ownership is considered inconsistent with the classification of the oil payment as B's mortgaged property. ${ }^{83}$ Such an argument seems entirely to ignore the many items in addition to interest which are usually added to the amount of the payment. ${ }^{84}$ For example, it is standard to add to the payment's face amount a sum to reimburse $\mathrm{C}$ for the state property and franchise taxes he will incur by holding the interest. Many other incidental expenses such as legal and recording fees are also taken into consideration in computing the amount of the oil payment. These practices certainly demonstrate the illusoriness of C's "independent ownership." 85

Adoption of the mortgage-loan approach would also eliminate an incongruity created by the present treatment of the ABC. That the purchase price of assets is not deductible when paid or incurred is an axiom of tax law. To recoup his investment, the taxpayer must rely upon depreciation, depletion or amortization deductions over the useful life of the asset. B's current treatment under the $A B C$ is an exception to this concept. He is not taxed on the income used to repay the financer (C), and the financed portion of the leasehold (the amount of the production payment) is not considered a part of his basis for depreciation or depletion. The net effect of this approach is to allow $\mathrm{B}$ a deduction for the financed portion of the purchase price as the loan is repaid, rather than having him recover his investment gradually by depreciation deductions over the useful life of the property. ${ }^{86}$ The mortgage-loan approach would also eliminate the taxable year problem raised by the carve out theory. If C's purchase of the production payment is treated as a loan of the purchase money to $\mathrm{B}$, $B$ would have taxable income only as the oil is produced. Adoption of the mortgage-loan theory in taxing $B$ would thus not only complement the proposed taxation of $\mathrm{A}$, but would also be more in line with economic reality.

\section{The Taxation of $C$}

$\mathrm{C}$ is the third principal in the $\mathrm{ABC}$, functioning as the financier of the transaction. His proceeds from the oil payment are currently taxed as

$83 A B C 23$.

84 For an accounting of the items added to the production payment in addition to interest, see Bullion, Production Payment Transactions-Recent Developments, 6 ROCKY MT. MINERAL L. INST. 81, 86 (1961). For a list of the items which the lending institution demands be added to the production payment, see Early 940-41.

85 One approach, however, would solve the whole question by arguing that since $B$ does not legally own the production payment, he could not secure a loan on it because he could not secure a mortgage on property he does not own. Therefore, it would follow that this could not be a loan situation. $A B C 20$. This reasoning is hardly inexorable.

86 Tanenbaum, supra note 81, at 161. 
ordinary income subject to depletion. ${ }^{87}$ Since C will ordinarily finance his purchase by borrowing from a bank, ${ }^{88}$ the latter will hold a mortgage on the production payment and an assignment of the oil runs. The bank will also be able to look to C's general credit for the satisfaction of his note. ${ }^{89}$ To compensate him for his participation in the $\mathrm{ABC}, \mathrm{C}$ will demand that the oil payment carry a higher rate of interest than that on his loan agreement with the bank. This spread is C's profit. ${ }^{00}$

Since the ABC depends upon C's financing, any attack upon his participation would have a direct effect upon the success of the entire transaction. One possible attack would be to bring $\mathrm{C}$ within the personal holding company provisions of the 1954 Code. ${ }^{91}$ Under current definitions, many C's would meet the necessary qualifications and could thus be subjected to the high tax rates applicable in such a situation. However, $\mathrm{C}$ need only distribute all its income to escape such treatment. If $\mathrm{C}$ is an exempt organization, ${ }^{92}$ the Service has another method for affecting its role in the ABC. The Service might simply withdraw C's nontaxable status if it finds that C's principal activity is one of financing oil and gas transactions. ${ }^{93}$ Although the oil payment is a relatively risk free investment bearing a good rate of interest, C's economic role is merely that of a lender, and ending C's exemption could be justified on the ground that its primary function is not to hold safe investments for charitable purposes

87 For discussions of C's taxation, see Minyard, How To Determine the Tax Saving That Makes an ABC Deal Worthwhile, $12 \mathrm{~J}$. TAxation 290, 292 (1960); $A B C$ 18-19. Since $C$ has a basis equal to the cash which he paid $\mathrm{A}$, he will usually employ cost rather than percentage depletion. Early 943-44.

88 In 1961, the Petroleum Division of Chase Manhattan Bank arranged for over $\$ 600,000,000$ of production payments on the $A B C$ with acquisition costs of approximately one billion dollars. Hulsey, New Problems in $A B C$ Financing, 13 INST. OIn \& GAS L. \& TAX. 539 (1962). Because it is dependent upon bank financing, the form of the production payment will many times be attributable to the demands of the bank. For an example of a typical provision a bank might want, see Purchaser 965.

89 Galvin 1501.

90 Sometimes this spread is required so that the lending institution can conform with the requirements of supervisory agencies that the funds advanced must be "loans," not "purchases." Bullion, Production Payment Transactions-Recent Developments, 6 Rocky Mr. MiNeral L. Inst. 81, 85 n.12 (1961).

$\vartheta 1$ If $C$ is a private business with more than half the value of its stock owned directly or indirectly by or for not more than five individuals and if at least $60 \%$ of its adjusted ordinary gross income is personal holding company income within the meaning of $\S 543$ (a) of the 1954 Code, then $C$ is a personal holding company under $\$ 542(\mathrm{a})$, and must pay a tax "equal to $70 \%$ of the undistributed personal holding company income" under \$541. Although C has a possible escape route from the $\$ 541$ tax under $\$ 543(\mathrm{a})(3)$, it is factually unlikely that he will be able to qualify thereunder. See Early 948.

92 If $\mathrm{C}$ is an exempt organization, income from a purchased oil payment is usually not subject to tax under $\$ 511$ (a) (1), since it is not considered as unrelated business income. INT. Rev. CODE of 1954, § 512(b) (2); Treas. Reg. \$1.512(b)-1(b) (1964).

93 If $\mathrm{C}$ has no other substantial assets and borrows the funds to purchase the payment, the Service may label this a passive investment and withdraw the exemption even though the return may be spent on charity. Appleman asserts that taxing only where there is borrowing is blatant "administrative legislation." ABC Deal 548. This particular Service tack is essentially the application of the ideas in Rev. Rul. 54-420, 1954-2 Cum. Bull. 128, which involved a foundation's purchase of the stock of a business corporation with payment of the purchase price deferred. The foundation obtained the assets in dissolution and sold, leased or licensed them to an operating 
but rather to help finance the oil and gas industry. ${ }^{94} \mathrm{~A}$ case by case approach would be required to determine whether $C$ fell within the spirit of the exempting statute. The motivation of such an investment, the possible inducements held out by the oil and gas industry, and investment alternatives should all be considered in reaching a conclusion on this question. For example, a hastily incorporated charity which was designed only to provide a receptacle for the oil payment would fail to qualify. On the other hand, the simple fact that an independent charity chose to utilize this mode of investment should not automatically deprive it of an exemption.

Because their chief effect is discouragement of participation in future $A B C$ transactions, neither of the above approaches speaks to the key issue raised by C's position in the ABC. This issue stems from the present classification of C's ownership of the oil payment. In oil taxation the person who has the economic interest in a certain property declares the income from the property. ${ }^{95}$ The current difficulty in attributing proceeds from the production payment to $B$ is not simply that $C$ has title to them, but rather that $\mathrm{C}$ is recognized as holding an independent economic interest because of his ownership of the production payment. In order to impress any attributive income theory upon the $A B C$, this treatment must be changed.

\section{The Production Payment: Whose Income?}

Where several individuals hold different interests in an income producing property, it will often be difficult to ascertain who is obliged to declare the income. Although the simple answer is that the "owner" is so obliged, it is difficult in such situations to decide who should be recognized as bearing this taxable identity. The problem may then be to ask whether the person who actually owns the underlying asset has divided his interest in the property only to divert income to another and thus to avoid taxes. If he has, the division will not eliminate his tax responsibility. This issue is not new to tax law ; the cases which speak to the subject distinguish between legal title to income as it flows from the property and basic tax

company, and the latter paid over most of its income as rents or royalties to the foundation. The foundation used $90 \%$ of this income to liquidate its debt. It was held that the foundation was not engaged exclusively in activities coming within the contemplation of the exempting statute, and that in any event the rents and royalties were income from an unrelated business. It was also declared that the use of income to retire indebtedness incurred in the acquisition of income producing property constituted an accumulation which might be unreasonable. See Early 952. Analogous to this situation is the "bootstrap" technique by which charities purchase businesses in order to give capital gains rather than ordinary income to the selling owners. For a discussion of this problem, see Lanning, Tax Erosion and the "Bootstrap Sale" of a Business, 108 U. PA. L. REv. 623 (1960); MacCracken, Selling a Business to a Charitable Fonndation, 1954 U. So. CAL. TAX INST. 205; Moore \& Dohan, Sales, Churches and Monkeyshines, 11 TAX L. REv. 87 (1956).

04 C's narrow profit spread, coupled with the wasting risk-type nature of the asset, have been cited in support of this conclusion. $A B C$ Deal 548 .

95 See Estate of Weinert v. Commissioner, 294 F.2d 750, 754-55 (5th Cir. 1961) (Wisdom, J.). 
responsibility for that income. ${ }^{96}$ The essence of this distinction was noted by Mr. Justice Stone in Helvering v. Horst ${ }^{97}$ when he stated that the income must be "realized" by the one "who owns or controls the source of the income." In a sense, the goal is to tax the person who is actually responsible for the production of the income-the person at the bottom of the investment.

These considerations are of equal importance in oil and gas taxation; indeed, the same distinction between legal title and tax responsibility is a basis of the Lake decision. Within this context it is at least arguable that $B$, and not $C$, is the party who is actually responsible for the production of the oil payment income. His ownership of the working interest would certainly seem to give him control of "the source of the income." In light of these considerations, the classification of C's holding as an economic interest must be reevaluated.

\section{Percentage Depletion and Economic Interests}

The concept of economic interest was a byproduct of certain changes made in the law of depletion allowances. To receive percentage depletion the taxpayer must possess an economic interest in the property. But ownership of such an interest, as mentioned above, carries with it the responsibility to declare the income from the property as well as the right to receive the benefit of depletion. It is thus reasonable to conclude that only an investor intended by Congress to receive the benefit of depletion should own the economic interest and be obliged to declare the income. The type of investment in the property that Congress intended to receive depletion is best revealed by tracing the history of percentage depletion.

When the income tax was first introduced, oil producers were allowed to write off as tax deductions the cost of all properties acquired after March 1, 1913. Because this procedure created serious inequitiesa highly valuable property could have been acquired at a low cost while a less productive property might have cost much more-Congress decided in 1918 to permit every discoverer to write off the value of the minerals in the ground. Two of its major purposes for adopting such an approach were to compensate for the high risk involved and to furnish an incentive for exploration and discovery. The new procedure required the taxpayer to establish market value within thirty days of the deposit's discovery; this value could then be written off as the minerals were produced. This new method, which was termed "discovery value depletion," led to several complications, many of which could be traced to the thirty day limitation. In 1926 Congress therefore developed the current system of percentage depletion. This system was intended to give the same result as discovery

26 Harrison v. Schaffner, 312 U.S. 579 (1941) ; Helvering v. Eubank, 311 U.S. 122 (1940); Helvering v. Horst, 311 U.S. 112 (1940); Blair v. Commissioner, 300 U.S. 5 (1937).

97311 U.S. 112, 116 (1940). 
depletion by providing a continuing deduction of twenty-seven and one half percent of the gross income from the oil and gas production. ${ }^{98}$

To receive this percentage depletion the taxpayer must possess an economic interest in the property. The Supreme Court, in the 1932 case of Palmer v. Bender ${ }^{99}$ established two requirements for such an interest: (1) the taxpayer must have acquired an interest in the minerals in place by investment, and (2) he must look to the income derived from the extraction of the oil for the return of his capital.

Under present tax treatment, the $A B C$ production payment is considered to meet the qualifications established in Palmer and is therefore accorded the status of an economic interest. It is true, of course, that $\mathrm{C}$ must look to the oil income for the return of his investment. It is also true that $C$ has, in a legal sense. made an "investment" which gives him an interest in the oil in place. Yet it does not follow that he has made the type of investment which should qualify as an "economic interest." Since the present scheme of depletion was designed to compensate for the risk involved in exploration and to furnish an incentive for initial investments, the reward of percentage depletion should only be given to those who are actually responsible for the development of the property. As Judge Wisdom has observed: "The issue is an economic one. The stake in the minerals is what counts: the income from oil and gas is taxable to the man who risks his stake to produce the oil and gas." 100 In sum, the history of percentage depletion indicates that Congress intended to give this benefit only to those investors who have taken a risk to develop the oil; it was not intended for investors who merely come in to buy rights to a certain amount of oil after the property is developed and producing. Onjy those who have made a risk bearing capital investment should be awarded an economic interest.

\section{The Nature of C's Interest}

$\mathrm{C}$ has not made such a risk bearing investment. Under the basic $A B C$ theory of independent ownership of the production payment, $C$ should be an equal investor with $B$; his risks and rate of return, however, are more analogous to those of a lender-creditor than to those of a risk bearing investor. ${ }^{101}$ The weightiest factors pointing to such a conclusion are the actual nature of what is being reserved and the positions of invest-

98 Texaco Oil Company, Percentage Depletron 4 (1964). The system also imposed a 50\% net income limitation as an upper limit for deductions.

99287 U.S. 551 (1932).

100 Estate of Weinert v. Commissioner, 294 F.2d 750, 756 (5th Cir. 1961). (Emphasis added.)

101 But see id. at 759:

A carried interest transaction or a carved out production payment may take the form of a loan with assignment by way of security, but it is a lending arrangement that would have been unfamiliar to Sir Edward Coke or William Blackstone. Its characteristics are so unlike a conventional loan that for modern tax purposes it should not be treated as loans are traditionally treated. 
ment in which the parties stand. C's interest is more a contractual right to collect a stated amount of money from the production of oil than it is an investment for development of the leasehold. His narrow and set interest margin does not resemble the type of profit associated with oil investments, but is more like that earned on a loan or a bond-like investment. The payment of a discounted ten dollars for ten dollars worth of oil is not a true risk investment. Although C's rights like those of an investor do eventually cease, this feature of his interest stems from the limits of the contract and not from the depletion of the oil. Moreover, although $C$ bears the entire risk that the production payment will not payout, the reality of that risk is questionable. As indicated above, the $A B C$ deal incorporates an oil payment with an almost certain payout. ${ }^{102}$ C's meaningful risks would therefore appear to be the market for the oil (which affects the quantity produced and the price received) and the production quotas imposed by state law. But interest rates (which compensate for any delay in payout) and fixed dollar amounts on the oil payment (which to a great extent nullify the market effect to $C$ ) make these risks negligible. ${ }^{103}$ Indeed, the interest being paid on the production payment is usually a little higher than that which $C$ would have received on a more solid security. ${ }^{104} \mathrm{C}$ 's risks are further reduced because his interest does not continue for the life of the lease, and his return therefore comes when the property is substantially undepleted. ${ }^{\mathbf{1 0 5}}$

These aspects of C's interest indicate that he has not made a risk bearing capital investment. He should thus have neither the right to depletion nor the right to be treated as owning an economic interest. On the other hand, B's interest would seem to qualify for both rights. It is $B$ who is actually at the bottom of the $A B C$. Possessing most of the economic rights in the property, $\mathrm{B}$ takes the actual risks in the transaction. Since he is dependent upon the market, and holds a long term investment which continues for the life of the lease, he assumes the hazard of over estimated reserves. B's interest is the type which was intended to receive depletion; he should thus be accorded an economic interest in the entire property and be responsible for declaring all of the income.

C's tax status will not be altered by reclassifying the nature of his interest in the oil payment. Under the current tax treatment, the nature of his loan-type investment will prompt $C$ to use cost rather than percentage depletion to recoup his investment costs tax free; the same result

102 See text accompanying notes 31-33 supra.

103 See Tanenbaum, supra note 81 , at 166.

104 See $A B C 21$.

105 C's security is also increased by a covenant which enables him to take over the property if B negligently operates it. Moreover, his security is further strengthened by B's obligation not to dispose of or sublease the property without C's consent. Purchaser 968 . There is actually a distinct similarity between this question and that of the stock-bond dichotomy in corporate taxation, where courts have not been hesitant to sort out the equity interests from the credit interests. For a complete discussion of this latter area, see BITTKER, FEDERAL INCOME TAXation of CoRporations aND SHAREHOLDERS 113-20 (1959). 
can be obtained by amortization. Such a procedure will give $\mathrm{C}$ the same tax result he presently receives, while leading to an economically sounder rationale for reaching that result.

\section{Conclusion: A Proposed Approach to the ABC Transaction}

\section{A. The Integrated Pattern}

Any proposal for changing the tax treatment of the $A B C$ transaction ${ }^{100}$ must determine whose tax status is to be altered. Since A has sold his entire asset, it would appear reasonable to award him capital gains on the proceeds. Viewing the A-B conveyance as a credit sale would not alter this result. C's status would also appear justified; despite the economic realties of his role in the transaction, he should still be permitted to obtain a return of his investment tax free. A denial of an economic interest

106 If any change in taxation were attempted, a controversial question would be whether the Service now has the authority to alter its long standing rules or whether it must instead wait for legislative action. It has been stated that long standing administrative practices of the Service have the effect of law where Congress has had both the knowledge and opportunity to legislate but does not. $A B C 24$; Ray \& Hammonds, The Income Tax on Proceeds from the Sale of Oil Payments: The Validity of G.C.M. 24849, 25 Texas L. REv. 121, 134 (1946). The Supreme Court spoke to this point in United States v. Leslie Salt Co., 350 U.S. 383 (1956), when the Service attempted to impose stamp tax liability on corporate notes. For years the Service had held such notes immune from taxation. The court held: "Against the Treasury's prior long standing and consistent administrative interpretation its more recent ad hoc contention as to how the statute should be construed cannot stand. Moreover, that original interpretation has had both express and implied congressional acquiescence ... through Congress having let the administrative interpretation remain undisturbed for so many years. . . " Id. at 396-97; accord Commissioner v. Estate of Marshall L. Noel, 380 U.S. 678 (1965) ; Cory Corp. v. Sauber, 363 U.S. 709 (1960) (per curiam); Cammarano v. United States, 358 U.S. 498 (1959).

Although the Service has issued ABC rulings for years, it would seem that there has not been any "express or implied Congressional acquiescence" in its treatment. In proposing legislation to deal with the carve out question there is evidence that Congress was aware of the ABC. See STAFFs of JoINT Comm. on INTERNAL. REvenUE Taxation \& the Treasury Dep't, 84th Cong., 2d Sess., List of Substantive UnINTENDEd Benefits aNd Hardships and AndtTonal Problems for Technical, Amendments BuI of 1957 (1956); Hearings Before the House Subcommittee on Ways and Means on Technical Amendments to the Internal Revenue Code, 84th Cong., 2d Sess., 259 (1956). From this, one author has asserted that "since Congress knew of the administrative practice of the Internal Revenue Service dealing with the $A B C$ transactions and made no change in that practice, it is clear that Congress has approved such treatment... [T] [Terefore there is no basis or authority for a change in this practice without Congressional action." $A B C$ 27-29. Although it could be argued that long standing administrative practice should not be lightly overturned, to assume that Congress approved of this method while dealing with another question seems highly tenuous, to say the least. See also Schoenbaum, New Legislation Regulations and Other Recent Developments Affecting the Taxation of Oil and Gas Income, 8 Tulane TAx Inst. 338, 355 (1959). See generally Surrey, The Scope and Effect of Treasury Regulations Under the Income, Estate, and Gift Taxes, 88 U. PA. L. REv. 556 (1940). Moreover, it must be remembered that Lake pointed out that prior administrative practice is always subject to change through exercise by the administrative agency of its continued rule making power. It would seem that if a certain treatment demands alteration the Service should be able to make such a change in order to give effective application to the Code. Only expressly purposeful congressional inaction should affect this rule. Such an approach would not conflict with the cases cited above, for they dealt only with whether administrative practices would be followed, and not with whether they could be changed by the Service. See Helvering v. Reynolds, 313 U.S. 428, 432 (1941) ; Helvering v. Wilshire Oil Co., 308 U.S. 90, 100-01 (1939). 
coupled with the allowance of amortization would render the same return. It is B's status which requires modification, for in allowing him to exclude the production payment proceeds from his gross income, B is granted a privilege not accorded similarly situated individuals under the Internal Revenue Code. Application of a mortgage-loan theory would eliminate this anomaly.

Adoption of the above theories would provide an integrated pattern of taxation for the ABC. As discussed above, if the A-B transaction is treated as a sale, A's retention of the oil payment should be treated as a mere debt obligation of $\mathrm{B}$, the purchaser. The conveyance from $\mathrm{A}$ to $\mathrm{C}$ could then be considered as a transfer of an account receivable. If this is a credit transaction for $A$, it should also be a credit transaction for $B$ and $C$. $C$ would be treated as holding a claim for money and would be considered a creditor-lender. Viewing the transaction in this light ties the $\mathrm{ABC}$ together into a logical pattern.

Bearing in mind that there have been no cases determining the tax consequences of $\mathrm{ABC}$ transactions, the above analysis would appear consistent with the present law. The A-B transaction is already considered to be a sale; moreover, treating an oil payment with a certain payout as a liquidated claim for money is borne out by the theory of Lake. Although the Internal Revenue Service has gone along with the present treatment, the authorities would seem to call for an application of the above approach.

\section{B. Economic and Noneconomic Interests}

The tax problems raised by the $\mathrm{ABC}$ and similar oil payment transactions can best be solved by reclassifying all production payments as either economic or noneconomic interests. A case by case factual analysis would be necessary to determine whether or not the holder has made the necessary risk bearing capital investment. All those interests-such as royalties-which continue for the life of the lease should be considered as economic interests, because the owner of such an interest risks his stake for the life of the lease, and actually gambles on the ultimate value of the developed reserves. Since the oil payment owner has an interest of limited duration, it would seem that the only situation in which he makes the necessary risk-type investment is where he invests in undeveloped property and receives an oil payment whose payout is uncertain. In such a situation, the holder does make a contribution to the development of the property and assumes an actual risk that the investment will not be returned. If the holder of the production payment has not made the necessary investment, both the right to depletion and the obligation to declare the income would devolve upon the person who is most responsible for the production of the income-in most instances, the owner of the working interest. Application of this working model would seem necessary to square taxation of the $\mathrm{ABC}$ transaction with economic reality. 